\title{
THE HORSE'S FRIEND
}

\section{BY}

GEORGE W. HEUSER.

It is not the appearance or size of this book that you pay for but the valuable information which it contains. 


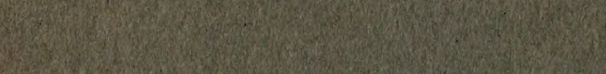

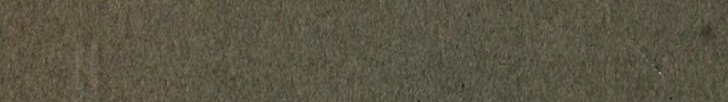

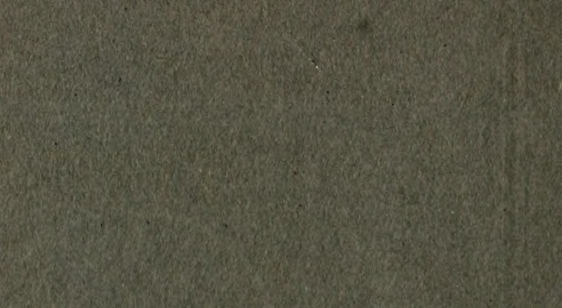

Q.

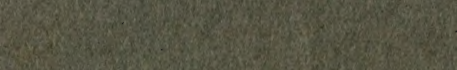

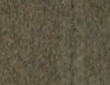

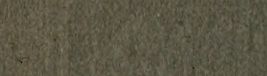

6.

$\cdot 7$

(19)

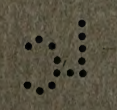

ing

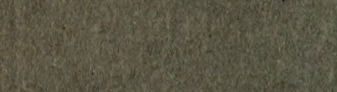

$+2 x$

g.

6.5.5.

0
$\bullet \vdots$
$\because \bullet:$

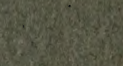

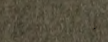

35

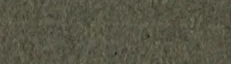

W.

(iving

20) 


\section{THE}

\section{HORSE'S FRIEND}

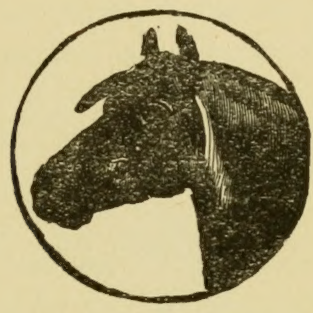

\section{GEORGE W. HEUSER AUTHOR AND WRITER}

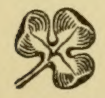

PENTECOSTAL PUBLISHING CO. LOUISVILLE, KY. 


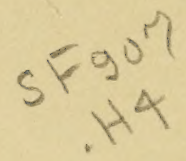

COPYRIGHT 1914

BY

GEORGE W. HEUSER

$\because \vdots \vdots$

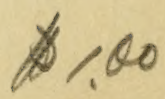

DEC 311914

(C) CIA 391198

Uo 


\section{PREFACE.}

I call this book the Horse's Friend because it contains remedies that will cure all evils about his feet and limbs. One who does not know cannot realize what injury it brings to a horse to have such ailments as corns, interfering, crooked feet and feet that are too long or too short, etc. Such defects bring about numerous other evils unknown to most people. The object of this little book is to call your attention to such evils and to give instructions and directions that if carefully followed will cure all such defects. A scientific and complete work on horseshoeing, showing the only correct method of shoeing a horse, such as has never before been given to the world. A book for the horse owner as well as the horseshoer. A horse owner can purchase this book and by following directions can have his horse shod accordingly and thereby get good results. It is worth $\$ 5.00$ a year to any horse owner if he has only one horse and that horse has any one of the defects mentioned in this book. About two-thirds of the horses the world over have one or more of these defects, and in some cases one horse may have them all. It is not the appearance or size of this book that you pay for, but the valuable information it contains. Buy it and try it, and be convinced that nothing as good has ever been offered you before. 
The people are wanting all these defects cured, and it can be done; they are dodging, and wandering around from place to place, trying to get it done, and they don't get it; if they did, all these things would not be.

To the horseshoer I would say, purchase one of these books and learn therefrom the only correct and proper way of shoeing a horse to cure the evils spoken of herein. By following the directions you can speedily arrive at the proper way of shoeing a horse. The horse owner who will study these directions can go to the horseshoer and tell him how to shoe his horse so as to get the results that he has been looking for.

The writer, George W. Heuser, is fully able to back up all he says in this book, and much more. If you will closely follow his directions, you will get the results you are looking for, and have looked for these many years.

For your own good and for that of the poor dumb animal, I ask you to interest yourself in the methods I have placed before you in this book. Follow the instructions given herein and these defects can be cured is guaranteed by the writer.

GEORGE W. HEUSER.

553 1st St., Louisville, Ky. 


\section{GEORGE W. HEUSER'S DISCOVERY}

\section{Full and Complete Discovery on How to Shoe Horses Properly.}

The greatest and most valuable discovery the world has ever known, has been made by the writer on horse-shoeing. How to cure corns, interfering, crooked feet, long feet, short feet, tender feet, etc.

Horse owners and horseshoers know there is more trouble about horseshoeing than any one thing on earth, and why? Because they don't know what to do. As long as horseshoeing has been in existence they have not yet seen the way herein described in this book, and this new and right discovery is now made by the author and writer, George W. Heuser, and given to the world.

If every horseshoer and every horse owner knew this discovery there would be no more trouble with horses' feet or about horseshoeing, but the man that owned the horse would take his horse to the shop and say, "Shoe my horse," and that would be all they would say; they would agree on the same thing exactly. The horse owner would not come into the shop and say, "Here, put on a long heel, or a short heel, or a crooked heel, or no heel at all," or say, "cut off one heel and leave the other on;" in all these cases the owner will suggest this or that and the horseshoer will say something or suggest something, and then they will exercise their ignorant efforts, hit 
or miss, and when this will not work, they will try a new idea that arises in their mind, just as absurd, and that is the way they have been doing as long as horseshoeing has been in existence. Consequently we have the city and country and whole world, full of horses with indescribable defects, such as they call creel foot, or pigeon toe, concave foot and anything but the right name and that name is, to-wit: crooked foot or crooked feet, and these things would not be if the horses were shod right, according to nature.

Would you not like to know what it is, horseshoers, and horse owners? Yes, I know you would. But the horseshoer may say, "I am a horseshoer and you can't teach me anything." Horse owners may say, "I know how a horse should be shod, but I can't do it." You are both wrong and mistaken. Neither of you ever saw a horse shod properly, where they have these defects, and there is a way to prove it.

You have already proven that you do not know this secret, by the way all horseshoers have been doing in the past, and are still continuing to do, and I will prove it more plainly than ever, if you will follow out the directions in this book.

Stop cutting off one heel of shoe, and leaving the other on. That only makes a rocker. If you cut one heel off, cut them both off But you ought not cut either of them off where you have a toe on a shoe. I know why you do it. You think it will stop interfering, or straighten a crooked 
foot, and it does neither, but is only an injury instead of a good, and does not stop interfering, and still you keep it up, just because you learned that way, and don't know anything else, and you see it in that way, and you see it entirely and altogether wrong.

Quit this old foolish custom and way, and follow out these directions, exactly as I describe them in this book, and you will succeed without a doubt, and never before, for these directions explain the only way on earth to stop a horse from interfering and all such defects. Don't shake your head and say, "No," but try it, and keep it up for two or three shoeings, and you will find it very simple and easy, and will be much surprised how good and reasonable it is.

I also did the same things, as you are doing now, and I thought it right also, and fought for it, as you do now, before I discovered this new and right way, and only way, and when you see it in the right way, you will also fight for it, for it is the only way to stop all these defects for good and cure a horse.

When you grasp this proper way to shoe a horse, you will say, as I say, there is nothing in the world to beat it, or equal it. It is a complete, finished way, and cannot be improved upon. It is a full, tried-out, developed success. It puts up a horse exactly according to nature, and assists nature, and it keeps the foot natural and straight, and makes the horse travel better and right. 
When once seen by a horseshoer, he will never shoe a horse any other way. It's as plain as the sun that shines, when once seen, simple and harmless, and more beneficial than man's mind can grasp, until he sees it; it makes it more easy to shoe a horse, for it is the only right way to do it.

I hope God will open your eyes and understanding to grasp this way, described herein, and that you will gladly quit the old fogy and miserable way that does not accomplish anything, but only gives the horseshoer worry and trouble to find what to do, and can't find it.

Now, after you have tried this natural way out, to the best of your knowledge and understanding, and say it will not work, I, the writer, will come to any address and show and prove to you that it will work, and if I do not prove it, I will pay my own expenses; and if I do, you are to pay expenses. But there is no if about it. I am fully able to prove it to the satisfaction of any man on earth.

I herewith give explanatory and full directions, as follows, to-wit: I will first take crooked feet, or pigion toe, as you may call it, because a crooked foot causes different bad things about a horse's travel. That is what causes interfering nine times out of ten. Nine cases out of ten, a horse that interferes his foot is more or less crooked, and if you will trim the outside of the foot, the foot will come straight, and the interfering will be stopped. The foot also wants to be 
well shortened, and you can't do it altogether by trimming it in the bottom of the foot, but let in the clip of the shoe well, at the toe, and the part of the foot that extends over on the inside, and a little on the outside; then pinch it off with the pinchers, then rasp it well up to the shoe. You will need to repeat this three or four shoeings, on a badly crooked foot, and even oftener if the foot is extra bad. Where the foot is not so crooked, one or two shoeings is sufficient, and will straighten them. You may say when the feet turn in toward each other that the inside of the foot is the longest. I say it is not, and there is no way for you to prove it. You just imagine it is thus. You will quit observing it in that way when you see the right way, which I have fully explained in this book.

A horse that wears his shoe on the outside proves to the biggest ignoramus that ever lived that the outside is the longer. And it is, and you know it, or at least you ought to know it, for the above explanation proves it, and there is another way of proving it, and that is to take a straw and measure from the top edge of hair of the leg down to the edge of the hoof, on each side, and you will find out the outside is longer. So when you trim the foot, or hoof, cut down the outside all it will stand and hardly touch the inside, in a bad case, and set the shoe well out at the toe, as well as at the heel, and you will get the results you have been looking for, perhaps for many 
years. You may say nature can't be forced. What is the reason then you are trying to force it in the very wrong way? If you follow out the above directions you will succeed. This which I refer to is not forcing nature, but assisting nature, so that the hoof or foot can come straight and right. You may say some horses are born with crooked feet, or hoofs and are crooked the first time they are shod; yes, that is so; and you shoe them two or three times and you will have them twice as crooked as they were when you started, so you are forcing nature from bad to worse, but if you follow the directions contained in this book, in such a case, you will have the foot or hoof twice as good in two or three shoeings, and have it straight and right. In every case you should have the shoe good and wide and full at the toe. Of course there is a difference. Some toes are naturally wider than others; some toes are narrow, and some are pointed. In cases of that kind the toe of the shoe should be a little wider than the toe of the foot or hoof. The toe of the foot will grow to it, as time goes by. Of course you ought to use some judgment, according to circumstances, sometimes, but the judgment and understanding of the different things about the foot or hoof will come to you as you grow into the knowledge of it.

You should study the foot or hoof some also, as you go along. Perhaps you have never studied the foot or hoof, much; and if you did you never 
understood it rightly. If you will continue to follow out all directions in this book, and use a little judgment, you will come out all right, and cannot miss it. When the toe of the foot or hoof comes to a point, like an old fashioned smoothing iron, you don't want to narrow or draw up the toe of the shoe, right to the toe of the foot or hoof; if you do, it will never get the toe of the foot any wider. Don't say no, but try and say, yes, yes! and get a move on yourself, and go after it, and get it; you can do so; it's laid down plainly here before you. I say, yes, yes, again; don't try to talk me out of it-out of something I know is right, and can prove it all along the line. You may say, "I have tried these things and they won't work." You have never tried and studied them thoroughly, or you would not say this. Perhaps you have tried some of these things I write about in a luke-warm way, and dropped them, and said they would not work.

I have talked to blacksmiths and horseshoers before now and they would say this way I speak of is right, and they would get right down and pick up the foot of a horse and do the opposite thing. I don't write this book to have you do the way you have been doing, for that is the wrong way. I want you to follow out these directions, and go after this most valuable thing to you on earth, and after you try hard and keep it up you will succeed, and in no other way.

Now if you cannot see that the side of the foot 
that strikes the ground first, and the most, and wears off the shoe the most, is the longest, then I will put it before you this way. Then you mean to say the inside of the foot that hardly touches the ground-you mean to say, cut it up still higher and get the inside still higher up, off the ground. Is that logic? It is not common sense, and it is not nature to raise the side that hardly touches the ground still higher. It is unreasonable. A boy ten years old ought to know better, whether he does or not, and you ought to also, but you don't. I don't mean to offend you, or make little of you, but I mean it for your good and the poor animal's good, and it would be good for both of you.

I hope God will not kill you for these awful things you have been doing, for you don't know any better, but I wish $\mathrm{He}$ would hit you a pretty good jolt and wake you up, and tell you to shoe horses right. Then maybe you would get your thinking cap on, and wonder what it is, that you are to do. Just like $\mathrm{He}$ did me. He gave me a grasp and showed me the right way and I believe it is a God-send to me, and it is intended for me to put it before the world, and I am going to do so, but enough of this at the present.

I will now take a long foot, where a horse wears out his shoe at the heel. First, it proves that his foot is too long and that is what makes him do it. The foot may be crooked with it also. In such a case trim the foot on the outside and 
let the shoe well in at the toe, and both defects will come right. Remember it will require more than one shoeing in anything like a bad case.

I will now take short feet or foot, which is generally the hind feet, and is caused by different things. Sometimes by a horse being graveled or by picking up a nail, which makes him stand up on his toe, sometimes a period of time, because it hurts him and becomes in such a habit of it that the leaders in the pastern joint become drawn up so that he cannot get the heel down to the ground. Of course when he travels he wears the shoe altogether at the toe. Such a case is hard to cure, but timely treatment and good shoeing will greatly help and assist such cases, and the way to help this kind of a case is to set the shoe well forward, just an ordinary shoe with a good, heavy toe, and high heels that will assist and help him more than anything else. Welding a lug of iron on the shoe in front or a clip, I suppose you call it, and letting it come over the front of the foot, is absolutely uncalled for, and no good, but injures the foot. The foot will never grow forward where they are put on the foot; it can't; the clip or lug of iron, holds it back, and the clip drags and wears off, and the toe is as short as ever, where if you take an ordinary shoe and set it well forward the foot is free from bondage and will grow forward. Of course it is hard for me to explain and give every little detail about the 
foot and shoe, but if I had you face to face, I could explain it better and easier, and I could show it still better.

Now, I will take into consideration another kind of a short foot, and that is, some horses get kind of leg worried or tired, or perhaps lazy and drag their hind feet a little, and drag the shoe or wear it into at the toe, and wear off a little of the toe of the foot or hoof. The next time you shoe him, you will set the shoe right back to the toe and perhaps let it in a little. Yet, right there and then you should set the shoe a little forward, and you will stop that right off. If that kind of a foot is turned in, trim it on the outside, and set the shoe a little forward, and you will cure both at once.

I have seen horses with their hind feet dragged or worn off very nearly half way back to their heels, and I have had that kind to come to my shop, and have cured them completely, just with an ordinary shoe. I have set the shoe forward as much as an inch or more at a time, and kept that up, and the foot will extend and grow gradually forward until it gets its natural length.

Don't say no, but say yes. I hope that you will plead for this, and use every effort and say, yes, some day with me.

Some feet are turned out, and the horse wears the shoe off on the inside. In such a case trim off the inside the most and set the shoe a little in, and it will come straight. If in such a case the 
horse should be interfering, he will stop interfering; but such cases are rare, and not so plentiful as those with feet turned in, and are easier cured.

I will now speak of corns, which is something a horse would not have if he was shod right. Corns come from having the shoes too narrow at the heel, or the foot too long, or both. In such cases trim the foot ordinary and let it in well at the toe; get the foot as short as possible, and that throws the weight more on the toe, and not so much on the heel. Make the shoe wide enough, so the heel of the shoe will come well out on the wall of the foot at the heel, so as to make the wall of the foot at the heel rest on the center of the iron, and the horse will never have corns, and where he already has them this will cure them. Treat a closed up heel or contracted heel, as one may call it, the same way. Let the wall at the heel come on the center of the iron, and the heel will spread, just the least bit; a closed heel can't be spread much, but a slight bit. In a case of an extremely narrow heel I would prefer turning the heel of the shoe out a little, a short curve or crook right at the very end of the heel of the shoe, a little like or similar to a mule shoe. I see horseshoers turning short curves or crooks on nearly all horses. It is absolutely uncalled for and unnecessary, except in an extremely narrow heel; in no case hollow out, or cup out the foot so much, as that is only an injury. You only cut out what 
is called the bar or brace of the feet, and it lets the foot shrink up and draw together; just trim to a gradual slope toward the center of the foot, just cupping it enough to keep the iron from resting too much on the sole of the foot.

I will call your attention to crooked feet and interfering again, as it may be necessary to give more understanding to some people and explain it more fully. As I said before about setting the shoe well out, you also want to make the shoe fuller and rounder on the outside than on the inside, it being full and round on the outside has a tendency to pull the foot out, when the horse goes to make his step, or helps to hold it out. You may say by setting the shoe out like I speak of, you can't drive the nails on the inside. Yes, you can, when you once understand the hoof or foot as you should. I have had cases where I set the shoe so as the inside of the hoof or foot extended over the shoe as much as a half inch or more, that means along toward the toe, and driven the nails high and dry, and you can do the same. Why, actually, you would have to bend or put out of place the ankle to make the foot come straight the way you have been doing, having the weight all on the outside of the foot. Just study it over a little and see if it is not plain, that you would have to bend the ankle to make the inside touch the ground or street, and the foot would not be straight, but the ankle bent, if it could be, but that is not possible. 
So, to make the inside of the shoe touch the ground or street, you must follow the directions in this book, and you will save all the unnecessary troubles, and the feet will come straight. You must closely follow the directions, and vary not from them, and then will the feet come right, and no other way.

That part of the foot that is turned in toward the other foot is not the longest, but is only a flap or wing, grown over toward the other foot, and you must cut off that flap or wing, and stop it from growing over toward the other foot, cutting it off with the pinchers and rasp after the shoe is nailed on.

All these things I speak of here for horses will work on mules, and it will also work on any kind of a mule or horse, from the commonest plug of a mule to the best race horse.

To give further details, and fuller understanding, I will give here an explanation on straight feet. For instance, should a horse interfere that has a straight foot, such a case is harder to cure than one with a crooked foot; it's because the foot is too long. Trim the foot ordinarily and a little more on the outside, than the inside, and make the outside of the shoe a little full, and round and let it well in at the toe; get the foot as short as possible, and the interfering will be stopped. In a bad case of interfering of any kind, I would prefer a flat shoe. The first shoeing after that, use any kind of a shoe you wish 
and it will be all right, but follow directions as above given. In a case of a horse forging or over-reaching you will weld plates or clips on the front part of the shoe, or toe of the shoe, which ever you want to call it, and let them run up on the front part of the foot, so as to remedy this defect, which is unnecessary. When above directions are followed the feet will come straight, and the horse will stop forging or overreaching.

You may think that I profess to cure many things, and may say that I say too much; no, I don't, and if you want more, I can give it to you, and if you don't I am going to give you more anyhow, for you need it. I am not through yet. I do not profess to have a secret remedy for each different ailment, or defect, but shoe a horse according to nature, and assist nature, and that is what makes all these cures, and you can do the same, if you follow directions. Don't say no, but get down and take hold of this great and most valuable way, and work for it and strive for it, and do the things laid down in this book. If you do them you will come to it, or you will do worse and worse, that is one thing sure. You have got to acknowledge this is the way to shoe a horse according to nature, or denounce it, and denouncing it will not profit you, so get it or die trying, for if these poor dumb animals could talk that would be as good a proof as you would need, but they can't, and you must be merciful to them and shoe them right, and this book is gotten to you 
for this purpose, to show you and plead with you that you are not doing the right thing in shoeing a horse. Another thing you do wrong in nearly all cases. You make the heel or calk too high, which makes it bad for the horse to travel. It pitches his foot forward too much, and ruts him too much like on stilts, and is unnatura?. more or less for him to travel. And yet another thing you do is to curve the shoe gradually from the toe to the heel downward, and that is also wrong as that makes another rocker lengthwise of the foot. So you have two rockers, one lengthwise and one sidewise. Now, should the horse travel right after you have put him in such a rocking position, besides all the other miserable, abominable things you do? It's all guess work what you do, and guess work has to come to a speedy end with me, and I can now say that I am sure of what I do and what can be done. I will now finish telling you about curving the shoe from the toe to the heel. It should be curved a little upward in place of downward, so as to make the shoe bind at the toe and heel; then when youl draw the nails the shoe will draw solid to the foot all along, and it's sure solid and not a rocker, and the horse has something solid to depend upon and help to make him travel right. You may say this will pinch or cramp his foot. It will not. if you let the wall come on the center of the iron at the heel. I will recall about bending the an!le which I spoke of before, which you would have 
to do in order to make the inside of the shoe touch the ground or street, and you do bend and spring the ankle over toward the other foot or leg every step the horse makes, but it flies back again. Now, don't you believe such a horse is in terrible misery and agony every step he takes? I know he is, but he can't tell it, or of course he would. Don't you know his ankle is on a strain all the time and that he is suffering all the time? Then why don't you quit making him stand on the outside of his foot or shoe by trimming up on the outside which is the only way on God's earth to do it. Horseshoers, will you do the right thing? Will ycu shoe the horses and mules the proper way? I plead with you earnestly and sincerely, will you come over on the right road of horseshoeing? I beg you, for pity sake, and for the sake of those poor dumb animals that are suffering right now, day in and day out, on account of lack of knowledge on the horseshoer's part, I beg you, to get down to business, and do the things which I have laid down before you in this book. You can do it. It's easy, simple and harmless as anything mind can think of, and as beneficial as gold can make anything. But I will have to move on. I want to call your attention to setting the shoe well out. As I have said heretofore, the inside nails will be very easy to drive, but the outside ones will be the most difficult to drive for a few shoeings until you get the foot pretty well spread out and 
straightened, then you can drive them all right. I have set the shoe so far out in some cases, sc that I would have to bend the nail just above the point in toward the hoof and right at the point bend them out a little more and get hold enough to hold the shoe all right. This is only where the hull has been broken off. Naturally, when you once understand this way of shoeing you will become more skilled in driving nails properly. If I knew what more to say to make it more clear to you or impressive, I would gladly do so, but I have already said enough to convince any intelligent man, horseshoer or horse owner, that when the inside of the foot is already the highest for a man in such cases, to get it in his head to trim it up still higher, there must be something wrong and there is. It's the lack of knowledge, and you will say so yourself when you once see this right, and only way to shoe a horse properly. In no case trim the foot so much as the average horseshoers do, but when you trim, trim at the right place. I have told you where and how, in an extremely long foot. Don't try to get it short enough by trimming in the bottom of the foot, but let the clip in well at the toe, as I said before, and that will shorten it quicker and better than any other way, and you will have to repeat this two or three shoeings before you get it short enough. You can't do it all at one time. The last thing before setting the shoe on the foot, rasp down the edges of the wall a little, not too 
much, so the shoe don't interfere with the sole of the foot or press on the sole too much.

Now I know just how impossible these things that I speak of, look to you. That is the reason I have said as much as I have. I want to make it as urgent and impressive on your minds as I can find words to do so, so as to get you to thinking, which I hope it will, as this is a sincere matter. Now you can say, think or talk what you please, but here it is laid down before you. The light, the truth and the way, and it means a great relief for those poor animals, horses and mules, if you will do these things, and follow these directions. I beg you once more in behalf of the poor animals to open your eyes and quit looking at these things wrong, and do this right and only way. Now if you want anything stronger than this I can give it to you, by coming to your place and proving it to you, and I will do so at your expense. Now, if there is any further information or explanation, you may want, write or call at my shop and I will gladly answer all questions and answer them correctly. You have perhaps heard men talk before now about horses being sure-footed. I have. They will say like this: "Such and such a horse is sure-footed." Any horse would be more sure-footed if he could be.

How in the name of common sense can a horse be sure-footed when he is walking on one side of his foot, which throws him in a rocker and wabble fashion. Such a horse has no certainty where 
it will land. He has got to throw his foot where he can and the foot being too long, makes it against him being sure-footed; and in some cases they have both the long foot and crooked foot, and then you will cut off the inside heel yet and put him on a double rocker, and then you will say, "Now, go horse and be sure-footed. We have put you on good rockers." $\mathrm{O}$, what a pity that you can't see any better than that. I feel sorry for you, and still more sorry for those poor animals, as they can't help themselves, but have to take what you give them. If the poor animals could only talk they would tell a pitiful story. They would say, "O! I'm in misery; can't you do something for me?" Now please wake up, open your eyes and look around; look in any direction and you will see nothing that will beat or equal what I have herein desccribed. If these directions are read and carefully followed there will be more good accomplished in one year for horses and mules than the world has ever accomplished in all the years past. Say, horseshoers and horse owners, there is more lameness on account of bad shoeing than any other cause, and if the horses and mules were shod this right and only way, there would be less lameness in horses and mules throughout the world, and it is good for the whole body of a horse as it assists his nature in every way.

Now a few words to race-horse men. You also do a few more miserable, outrageous, abomi- 
nable things to your horses in the way of shoeing than the ordinary horse shoer and horse owner considering the speed and time your horses have to make. You too, as the average horseshoers and horse owners, do and have done some of the most foolish, outrageous guess work that you can think of, and think and guesswork is all there is to it, and you don't know the right way. You guess, and you wonder and ponder and try everything but the right thing. You go all around the right way and leave it undone. You do like the ordinary horseshoers and horse owners do, and have things done that there is nothing in, such as cutting off the inside heel, shaping the foot wrong and shaping the shoe wrong. In nearly all cases you make the inside heel some shorter than the outside-that is wrong-make both heels the same length, as near as possible, and quit turning that outside heel out. You think that throws his feet or legs apart but it does not. It only throws them together if anything, and makes it unnatural and against him in different ways. I have seen men turn that outside heel out as much as an inch and turn it almost square, and others not quite so much, and others not at all. Now they can't all be right. Then I have seen some let the heel of the shoe extend back over the heel of the foot as much as an inch. They claim that this gives the horse spring heel and more speed. That is entirely wrong and nothing but imagination and another guesswork problem. The 
spring and speed have naturally got to be in the horse, in his limbs and nerves, and it is, that is, when he is shod right. Then nature can work its way through him. Why, there are lots of good speed and racehorses, but when they are shod against nature how are they going to do their best? Many a good racehorse's best is not known because he is not shod right.

Now another thing some of you do. You make roller motion shoes and knee action shoes. I don't know what they are, neither do you, nor any one else. There is no such thing and no place for them. They are no good whatever. The motion and action have naturally got to be in the horse. The right kind of shoeing is all that will make him have the right knee action and motion, and where the roller part comes in at I don't know, neither do you. It's just some more humbug, that's all, and there can be nothing proven by it.

Well, I will have to move along. I could say lots more in regard to the miserable things you do but time and space will not allow it. I can take a racehorse and shoe him and make him gain in speed anywhere, from 3 to 5 seconds in a mile heat, and you can too, if you just follow these directions, that is, where your horse has any of these defects. Of course race horses naturally have as many defects in their feet as the general work horse. I want to ask you a question, When the outside of the foot strikes the ground first which side is the longest or which side ought to be 
trimmed the most to make the inside come down flat on the ground? You can say nothing, only that the side that touches the ground first and most is the longest and should be trimmed most if you have any horseshoeing judgment about you at all. If the horse's foot is crooked, pigeontoed or turned in at the toe toward the opposite foot it proves that his foot is unnatural and not right, and he travels on one side of his foot, which throws him in a wabble or rocker fashion or shape. How can such a horse be as sure-footed as he would be if he could throw his foot down fiat and level. He can't be sure-footed and you know it, if he can't come down fiat and level with his feet. If you know any other way to make him put his foot down flat than to trim the side that comes on the ground first and most, I want to hear from you and see you prove it. You can't do it to save your life. You have tried it long enough. Now do the right thing and you will succeed and never before. That is, where the foot is turned in and crooked and wears off the shoe on the outside trim the outside of the foot the most, if the foot should be too long with the crooked foot shorten it by trimming it ordinary in the bottom, let in at the toe enough to make the foot the right length, set the shoe well out at the toe, making it a little more full and more round on the outside than on the inside as that has a tendency of pulling or holding the foot out when the horse goes to make a step. You will find that 
the foot will grow outward as time passes, not downward, but outward, and the foot will spread and you will get a nice, full, round, straight foot on your horse and he picks it up right and puts it down right-straight, level and flat-and you get all out of him there is in him, and in no other way. A horse can't do his best when one side of his foot is too long. Now do these things that I have told you and you will get the results you have long been looking for. Go after it and do it, don't be afraid of it hurting the horse or injuring him or his foot. There is no such thing as hurting him, if these things are done which I speak of, but it benefits him in every way, shape and form. The way you are doing and have been doing is injurious and harmful to a horse and is everything that is wrong. Study over it a little and see if you can't figure it out that when a horse is standing or traveling on one side of his foot and his ankle being bent and sprung and on a strain every breath he draws and every step he makes, see if you can't figure it out that such a horse is in misery and unnatural. Yes, he is bound to be so. Put him flat on his feet, then he will travel easy, active, and with more vigor be. cause it makes him feel better in every way.

Now I have told you how to do these things, so don't hesitate a moment but go and do it. The shoe should not extend back over the heel, but very little, if any, a little doesn't matter, and even as much as a half an inch wouldn't matter in 
some cases, but it does not give him any spring, as I said before, as the spring and speed have got to be in his limbs and nerves and it is, when his nature is assisted by shoeing the horse right and proper. Now do it and don't make an excuse and be wandering around trying and guessing. You have been doing that long enough. I bought a book a while back that a veterinary wrote only for mere curiosity. I knew before I bought it there was nothing to be learned in it about horseshoeing but it was really worse than nothing. Anyway, he gave his opinion and instructions which he thought were right, and it's all guesswork, just like the average horseshoer and horse owner. He said in the very last part of his book, these are the only means by which he believed the art of farriery can be improved in this country. When he says he believes it goes to show that he is just guessing at things and don't know for a fact if the things he speaks of are right or not. $\mathrm{He}$ uses a lot of big words and jawbreakers that one half the blacksmiths, horseshoers and horse owners can't understand and didn't say anything after all, and can't prove a thing, but I can say with a clear conscience and understanding that I do know and can prove every word I say and I will come to your place and prove it to you or any one. I don't care who you are. I will come at your expense. I have told you above how this veterinary also spoke of much lameness being caused by bad shoeing, but he failed to give the 
remedy that would cure this kind of lameness or prevent it. This is the remedy which I speak of when I say a horse should be shod according to nature. It assists nature and consequently there is much less lameness. If the horseshoers would all understand this way of shoeing and the horse owners would let them alone there would be 75 per cent. less lameness among horses the world over. Of course there is the horseshoer who knows something and the horse owner who knows something, and the coachman who knows something too, and then comes the veterinary, and he knows more than all of them put together, and he never picked up a horse's foot in his life to put on a shoe. And all of you together can't straighten a crooked foot or cure interfering or a bad case of corns or a foot that is too long or two short, and prevent the horses and mules from having all these defects unless you follow these directions.

Now if you should write me to come to your place to cure these defects I have written about, don't come to me with a deformed or crippled foot remember. I have seen horses and mules with their feet actually so crooked that the bottom of the foot was almost on top. They walked on the side of their foot so badly that they almost walked on the hair, and by walking that way so long the ankle became crooked. Such a case is a cripple and cannot be cured, but even such cases can be assisted and helped. Just such feet are 
caused by improper shoeing. That is what a man does by trimming up on the inside a little more each time he shoes a horse until he makes a cripple of him. But there are hundreds and thousands of cases that are not that bad that can be cured where if shod wrong will also make cripples of them in course of time. There is another kind of crippled foot or deformed foot, and that is where a horse walks extremely bad on his heel and throws his toe up when he steps. Such a case cannot be entirely cured, but can also be helped by trimming ordinary in the bottom and letting in well at the toe making the foot as short as possible and the shoe plenty large enough so as to make it long enough to extend back well over the heel making the heels of the shoe as heavy as possible that will help such feet. The veterinary's book I read also touched up a little on interfering, gave his ideas and guesswork. He said the fault laid in the horse and in the way he traveled, and that it could not be cured by shoeing alone. Yes, that is true, but what makes him travel wrong and awkward he failed to tell. I will tell you. It's that miserable, outrageous, awkward wrong way the horses are being shod, that's what it is. You go to work and shape the foot wrong, then shape the shoe wrong, and cut off one heel and make the heels too high, and put a horse in such a position and then blame him for not traveling right or for cutting his legs.

I will come and show you that when a horse is 
shod wrong he will travel wrong and when he is shod right he will travel right. I have told you what to do, so don't keep on doing or trying something else. There is nothing else to do except what I told you. This man that I read after spoke of different makes of shoes, and condemned some of the patterns very much and recommended a new kind of shoe. That's the trouble, there have been so many sorts and kinds of shoes recommended and the filing and shaping of them until the horses feet have got in the shape they are. It shows again that he is wondering and guessing and thinking there ought to be still another kind of shoe recommended. I will tell you what kind of a shoe is good. Any kind or pattern is all right. What we want now are men that know how to put them on right. Our factory shoes are made so good and perfect in shape that they can't be beat. I don't care if it's a home-made shoe the factory shoes are all good enough if they were only put on right. I have seen horseshoers take these nice, perfect shoes out of a keg and call themselves fitting them and they slam, bang, hammer and knock them around over the anvil from one end to the other a dozen times or more and actually when they got through with them they had a worse shape than when they started on them. It shows again that these guessers think more or less that it's in the shoe. They want to knock it out of the shoe and anvil. But the secret lies in the foot mostly, and you can't 
knock it out of the shoe or anvil. I don't care how much you hammer, jingle, ring, and slam around on the anvil it's not there, it's in the foot where the main trouble is, and when you once understand this way of shoeing that I speak of, it requires but little hammering to fit a shoe or prepare it for the foot. You may say the way I spoke of where I said about setting the shoe out so far as to make the inside of the hoof extend over the shoe as much as a half inch, then taking it off with the pinchers and rasp you may say that is fitting the foot to the shoe, but it is not, it is making the shoe and foot meet so as to get them both the right shape, and what you take off on the inside you gain on the outside by the foot growing outward. As time passes it grows outward and not downward and the foot will spread and you get a nice, full, round, straight foot on the horse, and when he puts it down he puts it down flat and level, and when he goes to travel he can go some and do it with ease and comfort. But when a horse is shod the way the average horseshoer shoes them he is in misery and dreads every step he makes. He don't know whether he is going to stand or fall, and if he stands it's a wonder and he has got to strain every nerve in him to do so. If he could talk he would tell you so. But enough, I am going to stop. If you want to know anything else write me. If you want the opportunity of seeing these things done I will show you at your expense, as I am fully able to do so. 
26. 65.

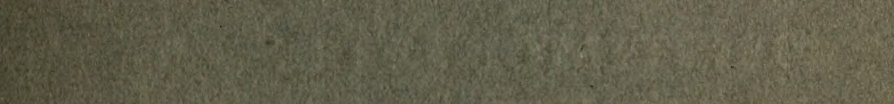

S. Q

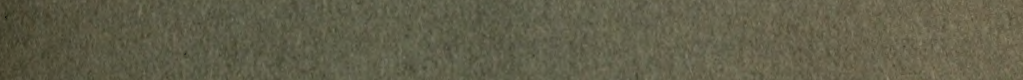

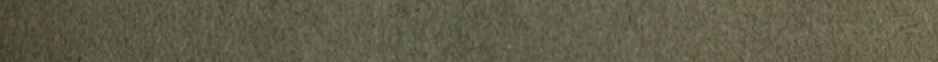

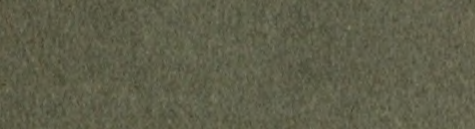

W.

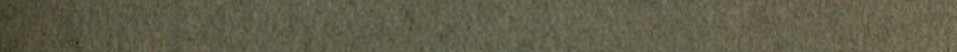

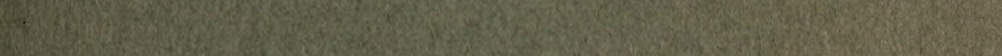
W.W. 6. Wha

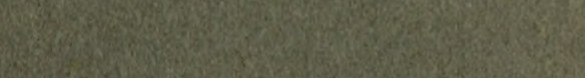

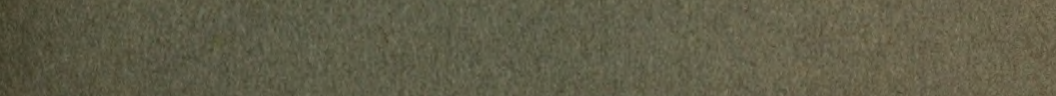
2.

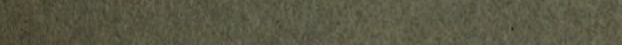
(3).

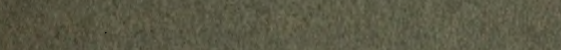

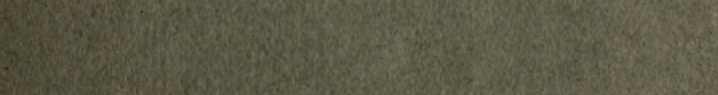
W.

W.

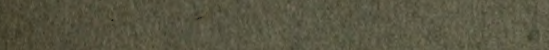

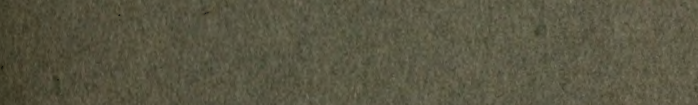
13. 45

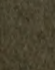
10.0. 


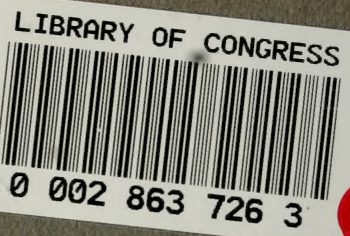

\section{TESTIMONIALS.}

Louisville, Ky., Sept. I6, I9I4.

This is to certify, that, during the years, when I owned and drove horses, I repeatedly called upon Blacksmith, George W. Heuser, when my horses were in trouble, on account of foot soreness or foot defects. Invariably. Heuser was able, in very short space of time, to correct these troubles. I considered him a veritable wizard, as a blacksmith, and never knew him to fail in the correction of so-called "interfering." Respectfully submitted,

\section{Leon L. Solomon.}

To Whom It May Concern:

Louisville, Ky., Sept. I8, I9I4.

I had a sorrel horse that interfered very badly. I tried several shoers in my neighborhood and none could do anything with him, so I sent him to Geo. W. Heuser, and he remedied the fault. Yours,

608 W. Jefferson St, Louisville, Ky. W. L. Drake.

Louisville, Ky., Oct. 9, Igr4.

My horse had crooked feet, wore off his shoes on one side, and interfered and wore off his hind shoes and feet very badly at the toe. Geo. W. Heuser, the writer of this book, cured him of all these defects.

IA33 Highland Ave, Louisville, $\mathrm{Ky}$.

Henry Sandfort.

Louisville, Ky., Sept. 18, 1914.

Several years ago I was driving a horse that interfered badly. George Heuser shod him for some months, and while he was wearing the shoes Mr. Heuser put on, the interfering stopped.

W. Ed. Grant, M. D.

Louisville, Ky. Sept. I9, IOI4.

At one time I had a horse that cut himself badly. Several horseshoers tried to remedy the matter and failed. As long, however, as he wore the shoes that George Henser placed on him he had no trouble.

J. M. Ray. 